\title{
AN INVESTIGATION INTO THE PRACTICES OF TRADITIONAL AND FAITH HEALERS IN AN URBAN SETTING IN SOUTH AFRICA
}

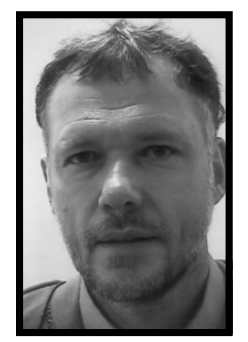

\author{
Prof. Karl Peltzer \\ Department of Psychology \\ University of the North
}

\section{ABSTRACT}

There is a lack of knowledge on traditional and faith healer's fees, practice and attitudes towards working within the government health sector. Therefore this study is aimed at investigating the above in an urban area in the Northern Province of South Africa. The objectives are: (1) to identify the demographic and practice characteristics of traditional and faith healers in an urban setting, (2) identify the conditions and problems commonly treated by traditional and faith healers, and (3) assess the referral details and willingness to work within the biomedical sector, the costs involved as well as the training needs. Semi-structured interviews were conducted with traditional healers $(n=20)$ and faith healers $(n=23)$ in an urban area in the Northern Province (South Africa) on socio-demographic characteristics, practice particulars, training, areas of specialisation, case load, the five commonest reasons for consultation, referral information, fees structure and attitudes towards government health service. As a result, it was found that both traditional and faith healers seem to treat a variety of problems and illnesses. Traditional healers seem to be more specialised in the treatment of sexually transmitted diseases and children's diseases, whereas faith healers are more specialised in substance abuse and chronic conditions as well as social problems. Both traditional and faith healers seem, at an equal level, to deal with witchcraft/sorcery related problems, physical disorders and mental disorders. Both traditional and faith healers hardly referred or got referred any patients in the last 4 weeks. Faith healers saw on average much more new (67) and old patients (54) patients in the last 4 weeks than traditional healers did (new patients: 9.6 and old patients: 6.1). Generally traditional healers seem to be more willing than faith healers to work within the government health service, irrespective of the place: in own premises, in a general practice surgery, or in hospital with out-patients.

\section{OPSOMMING}

Daar is gebrekkige kennis oor die fooie van tradisionele en geloofsgenesers en die praktyke en houdings ten opsigte van hulle werk in die gesondheidsdepartement van die staat. Hierdie navorsing is gemik op die bovermelde aspekte in ' $n$ stedelike gebied in die Noordelike Provinsie van Suid Afrika. Die doelwitte is soos volg: (1) om die demografiese en praktiese kenmerke van tradisionele en geloofsgenesers in ' $n$ stedelike konteks te identifiseer, (2) om die probleme en kondisies wat oor die algemeen deur tradisionele en geloofsgenesers behandel word te identifiseer, (3) en om die verwysings, gewilligheid om in die biomediese sektor te werk, koste aspek sowel as opleidings behoeftes vas te stel. Halfgestruktureerde onderhoude is met twintig tradisionele genesers en drie-en-twintig geloofsgenesers in 'n stedelike konteks in die Noordelike Provinsie in Suid Afrika gehou. Die onderhoude het die volgende aspekte behels: sosio-demografiese karaktertrekke, besonderhede oor praktyke, opleiding, spesialiteitsareas, kliëntelading, die vyfmees algemene redes vir konsultasies, inligting oor verwysings, fooie, en houdings oor die staat se gesondheidsdienste. 
Die resultaat van die ondersoek is dat beide tradisionele en geloofsgenesers ' $n$ verskeidenheid van probleme en siektes behandel. Tradisionele genesers spesialiseer meer in die behandeling van seksueel oordraagbare siektes en kindersiektes terwyl geloofsgenesers meer spesialiseer in dwelmmisbruik, kroniese toestande en sosiale probleme. Beide groepe behandel op gelyke basis heksery, fisieke afwykings en geestessiektes. Beide groepe het feitlik geen verwysings gemaak of gekry gedurende die afgelope vier weke nie. Geloofsgenesers het gemiddeld meer nuwe (67) en ou pasiënte (54) in die laaste vier weke as tradisionele genesers (nuwe 9.6 en ou pasiënte 6.1) gesien. Oor die algemeen is tradisionele genesers meer gewillig as geloofsgenesers om in die gesondheidsdepartement van die staat te werk ongeag die omgewing van die konsultasie: eie spreekkamer, algemene praktyk of in hospitaal vir buitepasiënte.

\section{INTRODUCTION AND PROBLEM STATEMENT}

The Northern Province is the most impoverished of the nine provinces in South Africa with a real GGP per capita of R 1712 in 1994. The area is largely rural with $91 \%$ of the inhabitants living in non-urban areas where access to health care facilities are inadequate (e.g. 2.4 hospital beds per 1000 people in 1992 and a physician: population ratio of less than 1: 20000). Health indicators are low (an infant mortality rate of 57:1000) (Development Bank of Southern Africa, 1998).

There is some resurgence of interest in traditional healing methods as practised by indigenous South Africans. Although traditional and western health care systems have operated side-by-side in South Africa since the advent of the Europeans, western healing has enjoyed greater formal (i.e. official) acceptance by successive previous governments because it was seen to be based on scientific and rational knowledge. In contrast, traditional and faith healing has been officially frowned upon and marginalised because it was perceived to be based on mystical and magical religious beliefs (Freeman \& Motsei, 1992). Before the April 1994 elections the African National Congress (ANC) proposed the following in its National Health Plan (ANC, 1994a:15):

"Traditional healing will become an integral and recognised part of health care in South Africa. Consumers will be allowed to choose whom to consult for their health care, and legislation will be changed to facilitate controlled use of traditional practitioners."

Soon after the elections, the new Government of National Unity formalised this policy in its Reconstruction and Development Plan (RDP) (ANC, 1994b:47f.): "There are deep divisions, fueled by mutual suspicion and lack of communication, between traditional and other complementary healers and medical and social workers. This is not in the interest of people who use all types of healers. The Reconstruction and Development Programme (RDP) must aim to improve communication, understanding and cooperation between different types of healers." Hopa, Simbaye and du Toit (1998:8-14) have investigated the perceptions on integration of traditional and western healing in the new South Africa. Different stakeholders (psychiatrists, medical doctors, psychologists, traditional healers and consumers) favoured the formal cooperation option for the integration of the two health systems.

As noted in South Africa and shown in other African countries traditional and faith healers play an important role in health care (Peltzer, 1987; 1998:49; 1999:390f.; Pretorius, 1989:101; ShaiMahoko, 1996:31). This may be expressed by the fact that for many South Africans the first choice of treatment is the traditional healer (De Beer in Swartz, 1986:276f.; Farrand, 1984:780; Louw \& Pretorius, 1995:41; Mabunda, 1999:102). Mabunda (1999:57ff.) surveyed hospital patients and staff, 
church members and university students in the Northern Province in South Africa and found that - according to the participants - a number of diseases can be best prevented or cured by traditional healing, e.g. witchcraft (like Sejeso and Sefolane) and ancestors (badimo) related problems, "traditional" diseases like Hlogwana (pulsating fontanelle; litt. 'little head'), Makgoma (assortment of ailments which follows the breach of particular taboos), infertility, sexually transmitted diseases, asthma, mental disorders, epilepsy, and diarrhoea while biomedicine was considered successful in diseases such as tuberculosis, chicken pox, AIDS, hypertension, diabetes, malaria, measles, cancer, anaemia, mental retardation, ulcers.

Freeman and Motsei (1992:1183) stated that there are broadly three types of traditional healers available to South African consumers. First the traditional doctor or inyanga. This is generally a male who uses herbal and other medicinal preparations for treating disease. Second the dingaka (Sotho). This is usually a woman who operates within a traditional religious supernatural context and acts as a medium with the ancestral shades. Third the faith healer who integrates Christian ritual and traditional practices.

There is a lack of knowledge on tradtional and faith healer's fees, practice and attitudes towards working within the government health sector. Therefore this study is aimed at investigating the above in one urban area in the Northern Province of South Africa. The objectives are: (1) to identify the demographic and practice characteristics of traditional and faith healers in an urban setting, (2) identify the conditions and problems commonly treated by traditional and faith healers, and (3) assess the referral details and willingness to work within the biomedical sector and costs involved as well as training needs.

\section{METHOD}

\section{Research design}

A quantitative survey.

\section{Sample and procedure}

Through local contacts, the healers and church organisations (Zionist and Apostolics) all traditional healers $(n=20)$ and faith healers $(n=23)$ in Mankweng (Northern Province of South Africa) were identified and interviewed through questionnaires by a research assistant.

The 1996 population census of Mankweng indicated a total population of 11233 , of which $29 \%$ were below 15 years of age. Mankweng is classified as urban because of its tertiary institutions (hospital, university and magistrate). Thus, the faith healer to population ratio was $1: 488$ and the traditional healer to population ratio was 1:561. The major language groups in this area are Sepedi (86.6\%), Xitsonga (5\%), Setswana (2.9\%), and others $(5.5 \%)$. Formal educational level among the population of 20 years and older was none (5\%), 1-6 years (3.1\%), and above 6 years (91.9\%) (Statistics South Africa, 1998).

\section{Measure}

A research assistant was trained by the author to conduct semi-structured interviews with closeended questions about socio-demographic characteristics of traditional and faith healers, practice particulars, and training; and open-ended questions on areas of specialisation, case load, the five commonest reasons for consultation, referral information, fees structure, attitudes towards government health service, and training needs. The questions were compiled from similar studies in rural South Africa (Peltzer, 1998:191; 1999:388) and from a complementary practitioners study in the UK (White, Resch \& Ernst, 1997:210). The interview 
schedule was pilot tested on a sample of 3 traditional and 3 faith healers (not part of the final research sample). Translation from English to Northern Sotho was double-checked by two bilingual researchers by means of back translation. The interrater reliability was found to be 0.8 . All qualitative data were recorded in Northern Sotho and subsequently translated in a team consisting of traditional and faith healers, researchers and Northern Sotho experts. The final study was conducted from middle of August to the end of October 1999.

\section{Data analysis}

For both close-ended and open-ended questions descriptive statistics were used.

\section{RESULTS}

The research assistant was able to interview 23 faith healers and 20 North Sotho individuals who labelled themselves as "traditional healers" (dingaka). Only 8 of the healers belonged to some or other 'healers' association. From the 23 faith healers 14 were Zionists, 6 Apostolics and 3 Born Again pastors.

\section{Demographic and practice characteristics of the traditional and faith healers}

Table 1 indicates the demographic and practice characteristics of the traditional and faith healers. Most faith healers (19) were male, whereas 10 traditional healers were male and 10 were female. The mean age in both groups traditional and faith healers was above 55 years. There was a clear difference with regard to formal education between traditonal and faith healers. Twenty-one (91\%) faith healers had more than 6 years of formal education (which is similar to the general population), whereas $12(60 \%)$ of the traditonal healers had less than 7 years of formal education. The majority of both faith and traditional healers considered themselves as full-time practitioners. Most traditional healers $(70 \%)$ considered themselves to be specialised in specific disorders whereas most faith healers $(70 \%)$ saw themselves as generalist healers. On estimate the faith healers clearly saw more clients a week $(M=97.5)$ than traditional healers $(M=35.5)$. However, the weekly income was rated higher among the traditional healers ( $\mathrm{R} 285.7$ ) than that among faith healers (R 135). Minimum and

Table 1: Characteristics of traditional and faith healing

\begin{tabular}{|c|c|c|}
\hline Variables & Traditional healers & F aith healers \\
\hline MIale (No): & 10 & 19 \\
\hline Female (No): & 10 & 04 \\
\hline Age (years) & $M=56.2(S D=13.2)$ & $M=59.5(S D=12.6)$ \\
\hline Formal education: None: & $45 \%$ & 0 \\
\hline 1-6 years: & $15 \%$ & $9 \%$ \\
\hline 7 years and above: & $40 \%$ & $91 \%$ \\
\hline Full-time practice & 12 & 20 \\
\hline Part-time practice & 08 & 03 \\
\hline Specialist in specific disorders & $70 \%$ & $30 \%$ \\
\hline Number of clients per week & $M=35.5(S D=9.5)$ & $M: 97.5(S D=21.3)$ \\
\hline Weekly income & Mean: R $285.7(S D=88)$ & $\begin{array}{l}\text { Mean: R } 135(S D=35) \text { (only } \\
\text { Apostolics, others like Zionists do } \\
\text { not charge) }\end{array}$ \\
\hline Minimum charges & Mean: R $40.3(S D=25)$ & Free \\
\hline Maximum charges & Mean: $692.8(S D=187)$ & $\begin{array}{l}\text { Mean: R } 225(S D=85) \text { (only } \\
\text { Apostolics) }\end{array}$ \\
\hline Mean age at which practice started & 36.1 years & 33.5 years \\
\hline Mean length of apprentice ship: & 7 months & $6(26 \%)$ none; 8 months \\
\hline Length of practice & 21.1 years & 28.9 years \\
\hline
\end{tabular}


maximum charges seem to differ a great deal. Most of the patients to consult the faith healer were estimated to come from within Mankweng area, whereas most patients to consult the traditional healer came from the district, the region or even the province.

Both traditonal and faith healers normally begun with their healing practice when they were over 30 years old and had been practicing for more than 20 years. The majority (16) of the traditional healers were combined diviners and herbalists, 2 were diviners only and 2 herbalists only. In this sample many of the tradtional healing resources were handed over from the family members who were traditional healers before the respondent was: grandmother (8), uncle (5), grandfather (4), father (2) and aunt (1). This was different for the faith healers, most (14) did not have a healer in the family before them and 9 had: grandfather (4), grandmother (3) and father (2).

\section{Most commonly treated conditions and problems by traditional and faith healers}

The illnesses, diseases or problems most commonly treated by the 20 traditional $(=\mathrm{TH})$ and 23 faith healers $(=\mathrm{FH})$ are listed below in Table 2. Multiresponses were possible. The number of reports of each condition or problem appears in brackets.

Both traditional and faith healers seem to treat a variety of problems and illnesses. Traditional healers seem to be more specialised in the treatment of sexually transmitted diseases and children's diseases, whereas faith healers are more specialised in substance abuse and chronic conditions as well as social problems. Both traditional and faith healers seem to deal at an equal level with witchcraft/sorcery related problems, physical disorders and mental disorders.

\section{Table 2 : Most commonly treated conditions and problems}

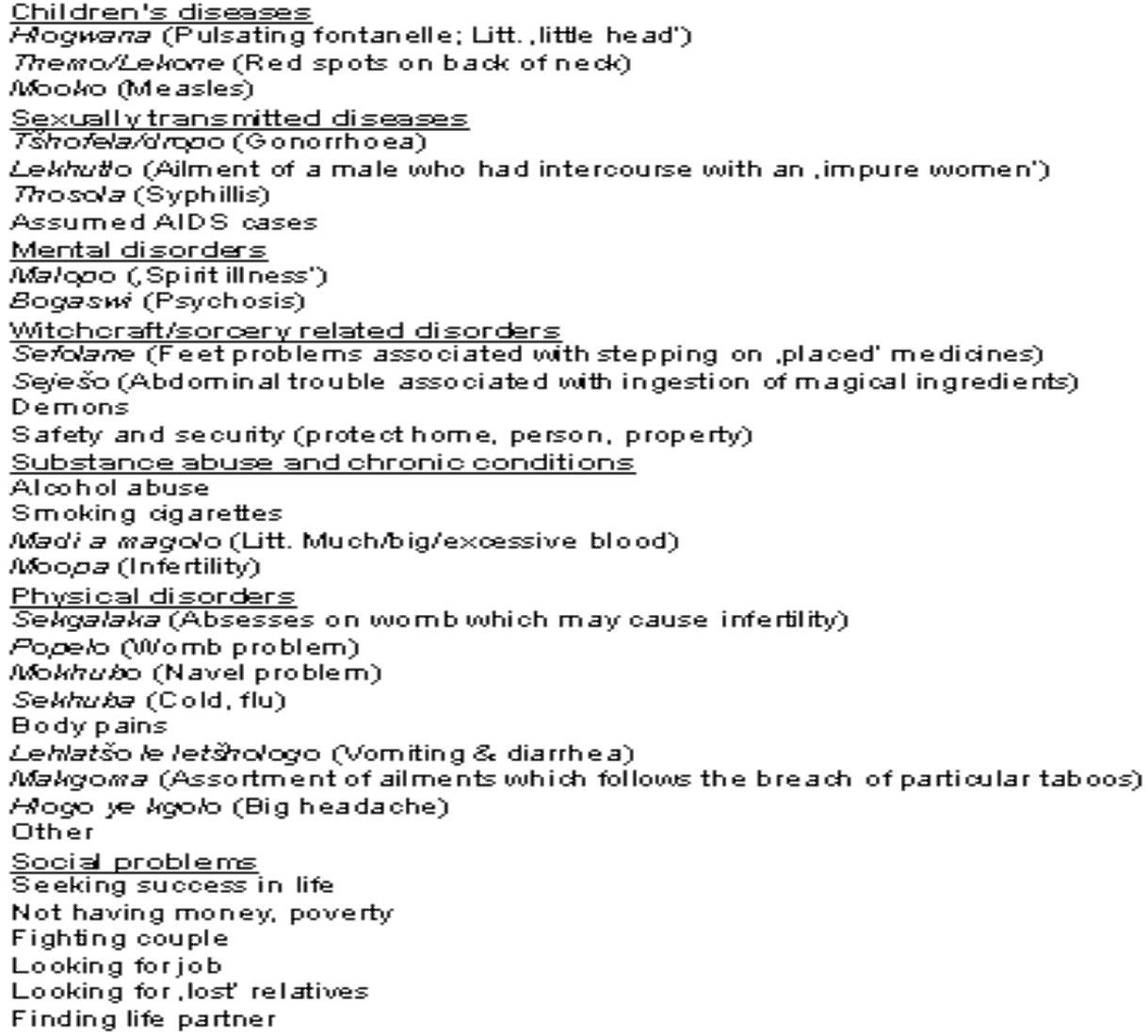




\section{Referral details}

Traditional and faith healers referred the following conditions to the biomedical health care system according to their rank: (1) AIDS, (2) Diabetes, (3) Asthma, (4) Tuberculosis, (5) Mental illness, (6) Sexually transmitted disease, (7) Epilepsy, (8) Stroke, (9) Bone fracture, (10) High blood pressure, (11) and others. Most
Epilepsy, (6) Painful legs, (7) Infertility, and (8) Other.

Table 3 indicates the number of referrals and patients seen by traditonal and faith healer.

Both traditional and faith healers hardly referred or got referred any patients in the last 4 weeks. Faith healers saw on average much more new (67) and old patients (54) patients in the last 4 weeks than

Table 3: Mean number of referrals and patients seen

\begin{tabular}{|c|c|c|}
\hline Mean number of referrals and patients seen & Traditional healer & Faith healer \\
\hline $\begin{array}{l}\text { Number of patients referred to you verbally by hospital in the last } 4 \\
\text { weeks }\end{array}$ & range: 0.9 & 0 \\
\hline Number of patients you referred to the hospital in the last 4 weeks & 0 & 1 \\
\hline Number of new patients seen in the last 4 weeks & 9.6 & 67 \\
\hline Number of old patients seen in the last 4 weeks & 6.1 & 54 \\
\hline
\end{tabular}

Table 4: Healers' willingness to work in various places within the biomedical health care sector

\begin{tabular}{|l|l|l|l|l|l|l|}
\hline & \multicolumn{3}{|l|}{ Not at all } & \multicolumn{2}{l|}{ Neutral } & \multicolumn{2}{l|}{ Very willing } \\
\hline Place & TH & FH & TH & FH & TH & FH \\
\hline In own premises & 5 & 13 & 2 & 2 & 7 & 3 \\
\hline In a general practice surgery & 6 & 15 & 2 & 2 & 6 & 1 \\
\hline In hospital out-patients & 4 & 13 & 5 & 0 & 5 & 3 \\
\hline
\end{tabular}

Table 5: Estimated average health service cost of a course of traditional or faith healing

\begin{tabular}{|l|l|l|l|l|}
\hline Type of healer & $\begin{array}{l}\text { Acceptable hourly } \\
\text { rate (Rand) }\end{array}$ & $\begin{array}{l}\text { First appointment } \\
\text { (min) }\end{array}$ & Subsequent & Total cost per patient \\
\hline Traditional healer & 53 & 35 & 27 & 58 \\
\hline Faith healer & 0 or 50 & 21 & 17 & 0 or 50 \\
\hline
\end{tabular}

traditional healers (18) and most faith healers (20) had referred patients to the modern health sector.

On the other hand, traditional and faith healers would like to have referrals from the biomedical sector for the following conditions according to their rank: (1) Bewitched/Demons, (2) Pray for patients in hospital, (3) Lekone, (4) Sefolane, (5) traditional healers did (new patients: 9.6 and old patients: 6.1).

\section{Willingness to work within the biomedical sector and costs involved}

Generally traditional healers seem to be more willing than faith healers to work within the government health service, irrespective of the place: on 
Table 6: Minimum acceptable hourly rate and number of hours offered by traditional and faith healers if employed

Traditional healer $\quad$ Faith healer

\begin{tabular}{lll}
\hline $\begin{array}{l}\text { Minimum acceptable rate (Rand) } \\
\text { Median }\end{array}$ & 60 & 0 or 70 \\
Range & $40-80$ & $50-100$ \\
$\begin{array}{ll}\text { Number of hours offered per week } \\
\text { Median }\end{array}$ & \\
Range & 44 & 42 \\
Not interested & $24-48$ & $30-48$ \\
\hline
\end{tabular}

own premises, in a general practice surgery, or in hospital with out-patients (see Table 4).

The estimated average health service cost of a course of healing seems to be more expensive for traditional than for faith healing (see Table 5).

The minimum acceptable hourly rate by traditional and faith healers if employed in the government health sector seem to be moderate to high (about $\mathrm{R}$ 50). Most traditional healers as opposed to faith healers were willing to offer large number of hours per week in government health service (see Table $6)$.

\section{Training needs}

Most faith healers (15) and some traditional healers (4) were not interested in any training. The others prioritised the following training needs in regard to disease categories in order of importance: (1) AIDS, (2) Tuberculosis, (3) Asthma, (4) STD, (5) Mental illness, (6) Cancer, (7) Diabetes, and (8) Other.

\section{DISCUSSION}

\section{Characteristics of traditional and faith heal- ers}

Most faith healers were male, whereas traditional healers were male and female in equal numbers. In the rural Northern Province it was also found that most faith healers are male but that most traditional healers were female (Peltzer, 1998:195; 1999:396). In this sample both traditional and faith healers were above 55 years of age, which was similar to rural traditional healers in the same Province (Peltzer, 1998:195) but higher than that found among rural faith healers (above 46 years) in the Northern Province (Peltzer, 1999:396), and also about 15 years higher than among urban traditional and faith healers in Zimbabwe (Winston, Patel, Musonza \& Nyathi, 1995:279). Similar to the urban healers in Zimbabwe, almost half of the sample studied considered themselves to have specialist expertise, whereas rural healers in South Africa seem to have been more generalist practitioners (Peltzer, 1998:195; 1999:390). Faith healers claimed to have seen on average 100 patients and traditional healers 35 patients per week, which seems much higher than rural healers in the province but similar to the urban healers mentioned in Zimbabwe (Chavunduka, 1994:55). In comparison, a primary care nurse in the Northern Province sees 32 patients a day (Dept of Health \& Welfare, 1996). It appears the traditional and faith healers in this urban area have become more full-time practitioners, more specialised and see more patients than their counterparts in the rural areas.

\section{Illnesses treated}

The illnesses and problems most commonly treated by traditional and faith healers in this study are similar to those reported elsewhere, the major conditions being witchcraft/sorcery related problems, 
mental disorders, and physical disorders. Traditional healers seem to be more specialised in sexually transmitted diseases and childhood disorders and faith healers in substance abuse and chronic conditions (Peltzer, 1998:195; 1999:395; Winston et al. 1995:280). Looking at the different illnesses treated, traditional and faith healing seem to play an important role in primary and especially mental health care. It is suggested that in order to improve the quality of traditional and faith healing the sectors in which they can be most effective should be identified - social problems, minor mental disorders, and substance abuse seem to be some of them.

\section{Referral, willingness to work within the gov- ernment health sector, and fee structure}

Traditional and faith healers had referred infectious, chronic and neurological disorders to the biomedical sector and made suggestions to receive referrals for the psychosocial and spiritual management of patients. Urban healers (about 90\%) seem to refer patients to the modern health sector more often than rural healers (about 20\%) in the province (Peltzer, 1998:195).

Generally traditional healers seem to be more willing and offer a considerable amount of hours than faith healers to work within the government health service. Faith healers explained that they feel more associated with the church in terms of practice and further training and would want to work only within their church context. In particular faith healers but also traditional healers did not indicate much interest in learning from the modern health sector apart from gaining more knowledge about the management of some infectious and chronic diseases.

The estimated average health service cost of a course of healing seem to be more expensive for traditional than for faith healing. The minimum acceptable hourly rate by traditional and faith healers, if employed in the government health sector, seem to be moderate to high (about R 50).
A clinical psychologist charges R 200 from medical aid for a therapy hour. Faith healers belonging to the Zion Christian Church did not ask for any fees and they would also not ask for fees if they were to work full-time, since they consider their healing practice a service to God.

The national health plan for South Africa (ANC, 1994a) indicates that there are numerous advantages in cooperation and liaison between modern and traditonal health practitioners and that interaction will be fostered. Traditional practitioners often have greater accessibility and acceptability than the modern health sector and_this will be used to promote good health. Mutual education between the two health systems will take place so that all practitioners can be enriched in their health practices.

\section{Recommendations}

It is recommended that faith healers should also be an integral and recognised part of health care, as suggested for traditional healers, in South Africa.

It is suggested that the more full-time and specialised traditional and faith healers in this urban setting should, in particular become involved in liason with the hospital services.

Research is needed on the efficacy of traditional healers, efficacy particularly with regard to sexually transmitted diseases and childhood disorders and faith healers in substance abuse and chronic conditions.

Looking at the different illnesses treated the role of traditional and faith healing should be promoted in primary and especially mental health care.

In order to improve the quality of traditional and faith healing the sectors in which they can be most effective should be identified - social problems, minor mental disorders, and substance abuse seem 
to be some of them.

\section{Acknowledgements}

The funding by the University of the North Research Office for the study and the research assistant MG Phaswana is hereby greatly acknowledged.

\section{REFERENCES}

African National Congress 1994a: A national health plan for South Africa. Johannesburg: Author.

African National Congress 1994b: The Reconstruction and Development Programme. Johannesburg: Author.

Chavunduka, GL 1994: Traditional medicine in modern Zimbabwe. Harare: University of Zimbabwe Press.

Dept of Health \& Welfare 1996: Health care in the Northern Province, implications for planning. Pietersburg: Health Systems Trust \& Dept of Health \& Welfare.

Development Bank of Southern Africa 1998: Northern Province Development Profile. Johannesburg: Author.

Farrand, D 1984: Is a combined western and traditional health service for black patients desirable? South African Medical Journal, 66:779-780.

Freeman, M \& Motsei, M 1992: Planning health care in South Africa: is there a role for traditional healers? Social Science \& Medicine, 34:1183-1090.

Hopa, M; Simbayi, LC \& Du Toit, CD 1998: Perceptions on integration of traditional and western healing in the new South Africa. South African Journal of Psychology, 28:8-14.

Louw, DA \& Pretorius, E 1995 The traditional healer in a multicultural society: the South African experience. (In: LL Adler \& BR Mukherji (eds.) Spirit versus scalpel: traditional healing and modern psychotherapy. Lon- don: Bergin \& Garrey. pp. 41-58.)

Mabunda, MM 1999: A cultural evaluation of the causes and treatment of diseases and other misfortunes among communities in the Pietersburg and Mankweng areas of the Northern Province. Sovenga: University of the North. (MA Dissertation in Anthropology.)

Peltzer, K 1987: Traditional healing and mental health care in Malawi. Heidelberg: Asanger.

Peltzer, K 1998: A community survey of traditional healers in South Africa (Northern Province). South African Journal of Ethnology, 21:191-197.

Peltzer, K 1999: Faith healing for mental and social disorders in the Northern Province (South Africa). Journal of Religion in Africa, 29:387-402.

Pretorius, E 1989: Skakeling tussen tradisionele en moderne geneeskunde in Afrika: die dekade sedert Alma Ata. Acta Academica, 21:101-129.

Shai-Mahoko, SN 1996: Indigenous healers in the North West Province: a survey of their clinical activities in health care in the rural areas. Curationis, 19:31-34.

Statistics South Africa, 1998: The people of South Africa population census, 1996. Pretoria: Author

Swartz, L 1986: Transcultural psychiatry in South Africa (Part 1). Transcultural Psychiatric Research Review, 23:273-303.

White, AR; Resch, KL \& Ernst, E 1997: A survey of complementary practitioners ‘ fees, practice, and attitudes to working within the National Health Service. Complementary Therapies in Medicine, 5:210-214.

Winston, CM; Patel, V; Musonza, T \& Nyathi, Z 1995: A community survey of traditional medical practitioners in high density suburbs of Harare. Central African Journal of Medicine, 41:278-283. 